\title{
Penerapan Suku Bunga Bank Indonesia sebagai Instrumen Utama Kebijakan Moneter di Indonesia Perspektif Ekonomi Islam ala Syafruddin Prawiranegara
}

\author{
Toufan Aldian Syah \\ Program Pascasarjana, IAIN Purwokerto, Indonesia \\ Email: toufan.aldiansyah86@gmail.com \\ Jamal Abdul Aziz \\ Program Pascasarjana, IAIN Purwokerto, Indonesia
}

\begin{abstract}
:
Monetary policy is a factor that greatly determines the economic conditions of a country. Because it is very closely related to various things of economic activity in the efforts to achieve economic development that provides welfare for the community. This paper seeks to analyse the mechanisms of monetary instruments in Indonesia. Second, look at the extent of the implementation of monetary policy mechanisms in Indonesia by using Bank Indonesia Interest Rates. Third, the views of one of the Islamic economic leaders namely Sjafrudin Prawiranegara regarding the prohibition of the use of interest rates in Islam. Based on the analysis and discussion described above, the researcher concludes that the mechanism of interest rate-based monetary policy instruments in Indonesia remains the main instrument in controlling the country's economics and cannot be directly considered contrary to Islamic principles.
\end{abstract}

Keywords: Monetary Policy, Syafrudin Prawiranegara, Interest Rates, Riba

\begin{abstract}
Abstrak:
Kebijakan moneter menjadi faktor yang sangat menetukan kondisi perekonomian suatu negara. Karena sangat erat kaitannya dengan berbagai hal kegiatan ekonomi dalam upaya pencapaian pembangunan ekonomi yang memberikan kesejaheteraan bagi masyarakat. Tulisan ini berusaha untuk menganalisa mekanisme instrumen moneter yang ada di Indonesia. Kedua, melihat sejauh mana penerapan mekanisme kebijakan moneter di Indonesia dengan menggunakan Suku Bunga Bank Indonesia. Ketiga, padangan salah satu tokoh ekonomi Islam yaitu Sjafrudin Prawiranegara mengenai pelarangan penggunaan suku bunga dalam Islam. Berdasarkan hasil analisa dan pembahasan yang telah diuraikan di atas, maka peneliti berkesimpulan bahwa mekanisme instrumen kebijakan moneter di Indonesia yang berbasis suku bunga masih tetap menjadi instrument utama dalam mengendalikan perekonomian negara dan tidak bisa langsung dianggap bertentangan dengan prinsip-prinsip syariah.
\end{abstract}

Kata Kunci: Kebijakan Moneter, Syafrudin Prawiranegara, Suku Bunga, Riba 


\section{PENDAHULUAN}

Kebijakan moneter berfungsi sebagai kunci untuk mencapai sasaran tujuan ekonomi makro dalam sebuah negara. Pemerintah melalui Bank Sentral selaku eksekutor kebijakan moneter terus berusaha mengatur jumlah uang yang beredar dengan berusaha memelihara kestabilan nilai uang dari berbagai faktor internal dan eksternal. ${ }^{1}$ Usaha tersebut dilakukan agar terjadi kesetabilan harga dan inslasi serta terjainya output keseimbangan. Hampir semua sektor ekonomi kapitalis terkait dengan sistem bunga, hal itu dikarenakan sistem bunga lebih cepat memberikan keuntungan dibandingkan dengan sektor riil. ${ }^{2}$

Sebagai salah satu instrumen kebijakan ekonomi makro, kebijakan moneter memiliki peran yang sangat penting dalam penyelesaian krisis ekonomi yang sedang terjadi di Indonesia. Apalagi mengingat bahwa krisis ini telah berkembang menjadi fenomena yang dikenal sebagai financial distress, yaitu proses demonetisasi berupa penurunan permintaan akan likuiditas perekonomian sebagai akibat meningkatnya permintaan akan uang kartal. Apabila dibiarkan terus berlanjut, proses ini akan menimbulkan dampak negatif terhadap pertumbuhan ekonomi jangka panjang. Pemicu terjadinya fenomena flight to currency yang begitu tiba-tiba adalah ketidak pastian nilai tukar rupiah. ${ }^{3}$ Oleh karena itu, upaya pemulihan ekonomi sangat tergantung kepada ketepatan strategi kebijakan moneter yang diambil, khususnya dalam rangka mengembalikan kepastian nilai tukar.

Strategi kebijakan moneter merupakan bagian dari kebijakan makro yang bertujuan untuk mengendalikan stabilitas nilai mata uang. Apabila stabilitas kegiatan ekonomi terganggu, maka salah satu kebijakan yang bisa digunakan adalah kebijakan moneter untuk memulihkannya dengan serangkaian tindakan stabilisasi. Ada beberapa penyebab kegagalan dalam pengendalian stabilitas nilai uang yaitu adanya ketidakstabilan pengganda uang (money multipler), velositas jumlah uang yang beredar (velocity of money) sampai dengan perubahan paradigma mekanisme transmisi kebijakan moneter.

Berbagai langkah yang dilakukan pemerintah selaku pengelola moneter di atas, perbankan merupakan salah satu sektor yang paling berperan dalam menjalankan kebijakan moneter. Krisis keuangan yang melanda Indonesia 1997-1998 merupakan kenangan terburuk dalam dunia perbankan Indonesia. Hal tersebut berdampak pada runtuhnya beberapa lembaga perbankan dan menambah beban tugas pemerintah untuk turun tangan dalam upaya menyelamatkan lembaga-lembaga kuangan dari krisis likuiditas. ${ }^{4}$ Ditambah dengan situasi sosial politik yang terus memburuk menambah panjangnya krisis keuangan yang melanda Indonesia. Sehingga menimbulkan permasalahan ekonomi di Indonesia yang semakin konflik.

Dengan adanya fenomena tersebut menimbulkan banyaknya ketidakpercayaan terhadap sistem perekonomian yang ada. Termasuk juga dalam pengelolaan kebijakan moneter yang berbasis suku bunga. Inilah yang kemudian menjadi perangsang terus berkembangnya lembaga keuangan yang berbasis Syariah. Pola kerja instrumen-instrumen

\footnotetext{
${ }^{1}$ Gregory Mankiw, Makro Ekonomi, Keenam (Jakarta: Erlangga, 2007), 499.

2 Muhamad, Ekonomi Moneter Islam, 1 ed. (Yogyakarta: UII Press, 2018), 207.

3 McNellis dan David Bigman, "Inventory Management and Economic Instability in High Inflation Economies: A Macrodynamic Simulation," Journal of Policy Modeling 10, no. 2 (1988): 224-47.

4 Veithzal Rivai, Islamic Risk Management for Islamic Bank (Gramedia Pustaka Utama, 2013), 540.
} 
kebijakan moneter syariah memiliki persamaan dan perbedaan prinsip dengan instrumeninstrumen kebijakan moneter konvensional. Sehingga menarik beberapa peneliti untuk melakukan studi empiris tentang kebijakan moneter yang diterapkan oleh negara Indonesia dengan menggunakan Suku Bunga Bank Indonesia sebagai salah satu instrument utamanya.

Tulisan ini disusun berdasarkan permasalahan yang muncul mengenai pro dan kontra penerapan sistem bunga yang dilarang oleh Islam. Namun sebenarnya dalam pandangan Sjafrudin Prawiranegara bahwasanya suku bunga dalam hal ini yang diterapkan oleh Bank Sentral yaitu Bank Indonesia tidaklah bertentangan dengan prinsip-prinsip Syariah, bahkan saling menguatkan satu sama lain. Perbedaan tulisan ini dengan penelitian mengenai pemikiran Sjafrudin Prawiranegara yang lain, terletak pada pembahasan mekanisme instrumen moneter yang ada di Indonesia dan penjelasan menganai manfaat penggunakan suku bunga dalam perekonomian negara dalam bentuk studi kasus.

\section{METODE PENELITIAN}

Penelitian ini menggunakan metode studi tokoh kritis yang merupakan salah satu dari jenis penelitian kualitatif. Dalam studi ini kapasitas peneliti adalah untuk menginterpretasikan dan menganalisis perjalanan seorang tokoh secara kritis. Teknik pengumpulan data dan informasi yang digunakan adalah teknik pengumpulan data kualitatif yang meliputi studi literatur. Dalam studi dokumentasi peneliti memanfaatkan sumbersumber catatan dan dokumen (non human resources) berupa dokumen, buku-buku tulisan yang menceritakan tentang kiprah Sjafrudin Prawiranegara dalam pengembangan pemikiran ekonomi Islam. Selain itu dalam penelitian ini juga menampilkan data-data perkembangan Instrumen moneter yang ada di Indonesia, khususnya pada saat krisis moneter untuk melihat bagaimana peranan suku bunga dalam aktivitas ekonomi.

\section{SUKU BUNGA DAN SIGNIFIKANSINYA DALAM PEREKONOMIAN}

Untuk dapat mengungkap secara lebih mendalam mengenai peranan suku bunga dalam perekonomian, maka kita harus terlebih dahulu memahami kebijakan moneter yang diterapkan dalam suatu negara. Dan seperti apa mekanisme yang dijalankan oleh Bank Sentral dalam hal ini Bank Indonesia dalam mengelola sistem keuangan negara.

Kebijakan moneter merupakan tindakan pemerintah yang dilakukan untuk mencapai tujuan pengelolaan ekonomi makro dengan jalan mempengaruhi situasi dan kondisi mikro melalui pasar uang atau dalam bahasa lain adalah proses penciptaan uang atau jumlah uang yang beredar. Oleh karena itu, kenijakan moneter merupakan kebijakan yang sangat penting disamping kebijakan fiskal dan kebijakan lainnya. ${ }^{5}$ Bofinger mengungkapkan hal senada dengan mengatakan bahwa kebijakan moneter merupakan upaya memanipulasi instrumen moneter untuk menjaga stabilitas harga, menekan angka pengangguran dan menjaga pertumbuhan ekonomi yang terus berkelanjutan. Otoritas pelaksana kebijakan moneter

\footnotetext{
5 I Wayan Sudirman, Kebijakan Fiskal dan Moneter: Teori dan Empirikal (Prenada Media, 2017), 67.
} 
dalam suatu negara biasanya dilakukan oleh bank sentral yang menjadi perpanjangan tangan pemerintah dalam memutuskan, mengatur, dan mengontrol kebijakan moneter. ${ }^{6}$

Kebijakan moneter di suatu negara dapat diimplementasikan dengan menggunakan instrumen moneter (suku bunga atau agregat moneter) yang mempengaruhi sasaran antara untuk mencapai sasaran akhir, yaitu stabilitas harga atau pertumbuhan ekonomi. Kebijakan moneter akan mempengaruhi perekonomian melalui empat jalur transmisi.7 Pertama, jalur suku bunga (Keynesian) berpendapat bahwa pengetatan moneter mengurangi uang beredar dan mendorong peningkatan suku bunga jangka pendek yang apabila credible, akan timbul ekspektasi masyarakat bahwa inflasi akan turun atau suku bunga riil jangka panjang akan meningkat. Permintaan domestik untuk investasi dan konsumsi akan turun karena kenaikan biaya modal sehingga pertumbuhan ekonomi akan menurun.

Kedua, jalur nilai tukar berpendapat bahwa pengetatan moneter, yang mendorong peningkatan suku bunga, akan mengakibatkan apresiasi nilai tukar karena pemasukan aliran modal dari luar negeri. Nilai tukar akan cenderung apresiasi sehingga ekspor menurun, sedangkan impor meningkat sehingga, transaksi berjalan (demikian pula neraca pembayaran) akan memburuk. Akibatnya, permintaan agregat akan menurun dan demikian pula laju pertumbuhan ekonomi dan inflasi.

Ketiga, jalur harga aset (monetarist) yang berpendapat bahwa pengetatan moneter akan mengubah komposisi portfolio para pelaku ekonomi (wealth effect) sesuai dengan ekspektasi balas jasa dan risiko masing-masing aset. Peningkatan suku bunga akan mendorong pelaku ekonomi untuk memegang aset dalam bentuk obligasi dan deposito lebih banyak dan mengurangi saham.

Keempat, jalur kredit yang berpendapat bahwa kebijakan moneter akan mempengaruhi kegiatan ekonomi melalui perubahan perilaku perbankan dalam pemberian kredit kepada nasabah. Pengetatan moneter akan menurunkan net worth pengusaha. Menurunnya net worth akan mendorong nasabah untuk mengusulkan proyek yang menjanjikan tingkat hasil tinggi tetapi dengan risiko yang tinggi pula (moral hazard) sehingga risiko kredit macet meningkat. Akibatnya, bank-bank menghadapi adverse selection dan mengurangi pemberian kreditnya sehingga laju pertumbuhan ekonomi melambat.

Pelaksanaan kebijakan moneter yang umum dilaksanakan menggunakan empat instrumen utama, yaitu dengan melakukan alur-alur berikut: 8

a. Kebijakan Pasar Terbuka (Open Market Operation). Kebijakan ini dilakukan bank sentral dengan cara membeli atau menjual surat berharga atau obligasi di pasar terbuka.

b. Penentuan Cadangan Wajib Minimum (Reserve Requirement). Kebijakan ini dilakukan bank sentral dengan menentukan angka rasio minimum antara uang tunai (reserve) dengan kewajiban giral bank (demand deposits) atau yang biasa disebut dengan minimum legal reserve ratio.

\footnotetext{
6 Peter Bofinger, Monetary Policy: Goal, Institutions, Strategies and Instrument (New York: Oxford University Press, 2001).

${ }^{7}$ Sjamsul Arifin, "Efektifitas Kebijakan Suku Bunga Dalam Rangka Stabilisasi Rupiah Di Masa Krisis," Buletin Ekonomi Moneter dan Perbankan 1, no. 3 (11 Oktober 2003): 4.

8 Manurung, Uang, Perbankan, dan Ekonomi Moneter (Jakarta: Fakultas Ekonomi Universitas Indonesia, 2004).
} 
c. Penentuan Discount Rate. Bank sentral selaku sumber dana lembaga keuangan lainnya dapat memberikan pinjaman dengan tingkat suku bunga lebih kecil dibawah tingkat suku bunga jangka pendek yang berlaku di pasar.

d. Moral Suasion atau kebijakan bank sentral yang berbentuk himbauan, bujukan, atau pengawasan moral terhadap tindak tanduk dari para bankir agar selalu terarah pada kepentingan masyarakat dan nasabah yang telah mempercayainnya.

Kerangka Operasi Kebijakan Moneter yang dilaksanakan di Indonesia memiliki empat sasaran utama yang dijelaskan sebagai berikut;

a. Instrumen-instrumen Moneter

Instrumen pengendalian moneter merupakan alat-alat operasi moneter yang dapat digunakan oleh Bank Sentral dalam mewujudkan tujuan akhir yang telah ditetapkan. ${ }^{9}$ Instrumen-instrumen kebijakan moneter terdiri dari: (1). Operasi Pasar Terbuka (OPT), (2).Tingkat Bunga Diskonto, (3). Giro Wajib Minimum (Reserve requirement), (4). Himbauan Moral. ${ }^{10}$

b. Sasaran Operasional (Operational Target)

Sasaran operasional merupakan sasaran yang ingin segera yang dicapai oleh Bank Sentral dalam operasi moneternya. Variabel sasaran operasional digunakan untuk mengarahkan tercapainya sasaran antara. Kriteria sasaran operasional antara lain: (1). Dipilih dari variabel moneter yang memiliki hubungan yang stabil dengan sasaran antara, (2). Dapat dikendalikan oleh Bank Sentral, (3). Akurat dan tidak sering direvisi.11

c. Sasaran Antara (Intermediate Target)

Hubungan antara sasaran operasional dan sasaran akhir kebijakan moneter bersifat tidak langsung dan kompleks serta membutuhkan time lag yang panjang. Untuk alasan itu, para ahli moneter dan praktisi Bank Sentral mendesain simple rule untuk membantu pelaksanaan kebijakan moneter dengan cara menambahkan indikator yang disebut sebagai sasaran antara. Sasaran tersebut merupakan indikator untuk menilai kinerja keberhasilan kebijakan moneter, sasaran ini dipilih dari varibel-variabel yang memiliki keterkaitan stabil dengan sasaran akhir, cakupannya luas, dapat dikendalikan oleh bank sentral, tersedia relatif cepat, akurat dan tidak sering direvisi. Variabel sasaran antara meliputi: agregat moneter (M1 dan M2), kredit perbankan dan nilai tukar. ${ }^{12}$

d. Sasaran Akhir (Final Target)

Sasaran akhir kebijakan moneter yan g ingin dicapai oleh Bank Sentral tergantung pada tujuan yang dimandatkan oleh UU bank sentral suatu negara. Tujuan akhir kebijakan

\footnotetext{
${ }^{9}$ Solihin dan Suseno, Uang: Pengertian, Penciptaan, dan Peranannya dalam Perekonomian, Buku Seri Kebanksentralan No.1 (Jakarta: Pusat Pendidikan Dan Studi Kebanksentralan (PPSK) Bank Indonesia, 2002), 26.

${ }^{10}$ Ascarya, Instrumen-Instrumen Pengendalian Moneter, Buku Seri Kebanksentralan No. 3 (Jakarta: Pusat Pendidikan Dan Studi Kebanksentralan (PPSK) Bank Indonesia, 2002), 51.

${ }^{11}$ F.S Miskhin, The Economics of Money, Banking and Financial Markets, Seventh (New York: Pearson Addison Wesley Longman, 2004), 347.

12 Bofinger, Monetary Policy: Goal, Institutions, Strategies and Instrument, 125.
} 
moneter di Indonesia mengacu pada Pasal 7 ayat (1) UU Nomor 3 Tahun 2004 yang secara eksplisit mencantumkan bahwa tujuan akhir kebijakan moneter adalah mencapai dan memelihara kestabilan nilai rupiah (stabilitas moneter).

Secara spesifik Taylor (1995) menyatakan bahwa mekanisme transmisi kebijakan moneter adalah "the process through which monetary policy decision are transmitted into changes in real GDP and inflation". Artinya, MTKM merupakan jalur-jalur yang dilalui oleh kebijakan moneter untuk dapat mempengaruhi sasaran akhir kebijakan moneter yaitu pendapatan nasional dan inflasi. Pada Skema 1 terlihat kotak hitam yang merupakan area MTKM atau jalur-jalur yang dilalui oleh suatu kebijakan moneter hingga terwujudnya tujuan akhirnya kebijakan moneter yaitu inflasi.

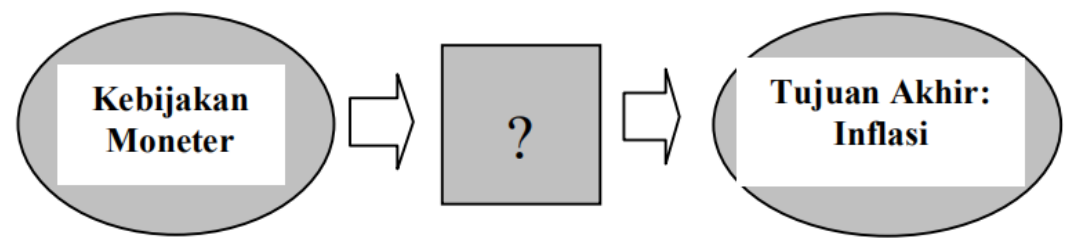

Skema 1

MEKANISME TRANSMISI KEBIJAKAN MONETER SEBAGAI "BLACK BOX"

Secara teoritis, konsep standar mekanisme transmisi kebijakan moneter dimulai dari ketika bank sentral mengubah instrumen-instrumennya yang selanjutnya mempengaruhi sasaran operasional, sasaran antara dan sasaran akhir. Misalnya Bank Sentral (BI) menaikkan SBI. Peningkatan tersebut akan mendorong naiknya Suku Bunga Pasar Uang Antar Bank (PUAB), suku bunga deposito, kredit perbankan, harga aset, nilai tukar dan ekspektasi inflasi di masyarakat. Perkembangan ini mencerminkan bekerjanya jalur-jalur transmisi moneter yang akan selanjutnya berpengaruh terhadap konsumsi dan investasi, ekspor dan impor yang merupakan komponen permintaan eksternal dan keseluruhan permintaan agregat.

Secara empiris, besarnya permintaan agregat tidak selalu sama dengan penawaran agregat. Jika terjadi selisih antara permintaan dan penawaran atau terjadi output gap maka akan memberi tekanan terhadap kenaikan harga-harga (inflasi) dari sisi domestik. Sementara itu, tekanan inflasi dari sisi luar negeri terjadi melalui pengaruh langsung dan tidak langsung perubahan nilai tukar terhadap perkembangan harga barang-barang yang diimpor.

Pada awalnya pelaksanaan kebijakan moneter hanya ditransmisikan melalui Jalur Uang (money channel). Tapi, seiring dengan kemajuan di bidang ekonomi dan keuangan serta perubahan struktural dalam perekonomian, maka jalur-jalur MTKM berkembang menjadi enam jalur, salah satu di antaranya adalah Jalur Suku Bunga. ${ }^{1314}$ MTKM melalui Jalur Suku Bunga menekankan peranan perubahan struktur suku bunga di sektor keuangan. Pengaruh perubahan suku bunga jangka pendek ditransmisikan kepada suku bunga menengah/panjang

13 Miskhin, The Economics of Money, Banking and Financial Markets, 125.
14 Bofinger, Monetary Policy: Goal, Institutions, Strategies and Instrument, 45.

116

Iqtishadia:Jurnal Ekonomi dan Perbankan Syariah

Vol. 7 No. 2 Desember 2020 
yang selanjutnya mempengaruhi permintaan dan pada akhirnya berpengaruh terhadap inflasi. ${ }^{15}$

Kebijakan moneter yang ditransmiskan melalui Jalur Suku Bunga dapat dijelaskan dalam dua tahap: Pertama, transmisi di sektor keuangan (moneter). Perubahan kebijakan moneter berawal dari perubahan instrumen moneter (SBI) akan berpengaruh terhadap perkembangan suku bunga PUAB, suku bunga deposito dan suku bunga kredit. Proses transmisi ini memerlukan tenggat waktu (time lag) tertentu.

Kedua, transmisi dari sektor keuangan ke sektor riil tergantung pada pengaruhnya terhadap konsumsi dan investasi. Pengaruh suku bunga terhadap konsumsi terjadi karena suku bunga deposito merupakan komponen dari pendapatan masyarakat (income effect) dan suku bunga kredit sebagai pembiayaan konsumsi (substitution effect). Sedangkan pengaruh suku bunga terhadap investasi terjadi karena suku bunga kredit merupakan komponen biaya modal.

Pengaruh suku bunga terhadap konsumsi dan investasi selanjutnya akan berdampak pada jumlah permintaan agregat. Jika peningkatan permintaan agregat tidak dibarengi dengan peningkatan penawaran agregat, maka akan terjadi output gap (OG). Tekanan OG akan berpengaruh terhadap tingkat inflasi. Mengacu pada penjelasan di atas, maka dapat dikatakan bahwa inflasi yang terjadi melalui jalur ini adalah inflasi akibat tekanan permintaan (demand pull-inflation). MTKM melalui Jalur Suku Bunga dapat disimak pada Skema 2.

Skema 2

Mekanisme Transmisi Kebijakan Moneter Melalui Jalur Suku Bunga

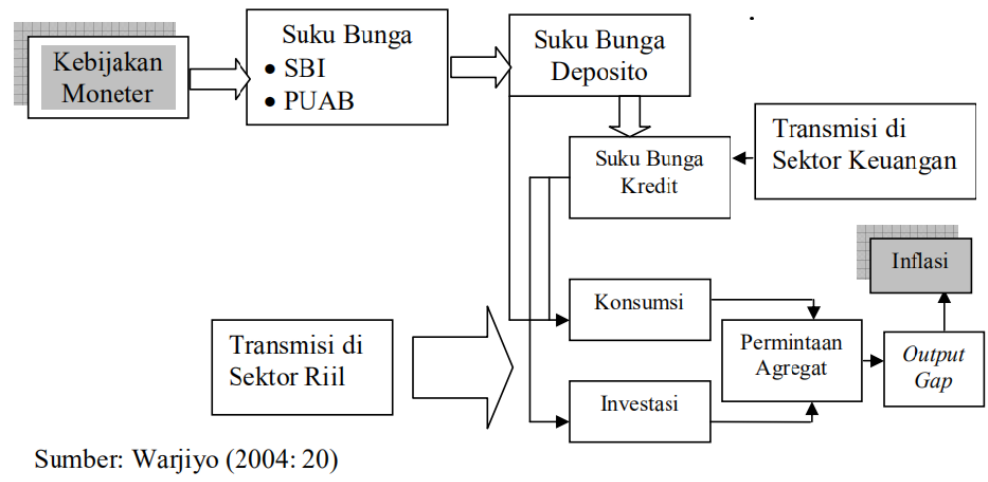

Adapun dampak suku bunga dalam perekonomian dapat dilihat dari beberapa sektor berikut:

a. Sektor Perbankan dan Pasar Modal

Sektor perbankan telah mengidap berbagai kelemahan sebelum terjadinya krisis seperti tercermin pada besarnya jumlah kredit macet pada sejumlah bank. Dengan terjadinya krisis yang mengakibatkan pemerintah mengambil kebijakan ketat, di samping serbuan rush berulang-ulang, sektor perbankan menjadi semakin terpuruk

15 Bofinger, 80 . 
karena disintermediasi perbankan sudah terjadi sejak akhir 1997 dan kualitas aktiva produktif juga semakin memburuk akibat spread negatif dan lebih dari 100 bank melanggar GWM dalam triwulan pertama 1998. Dalam keadaan perbankan seperti ini, program rekapitalisasi akan memerlukan biaya yang sangat besar.

Berdasarkan teori, suku bunga berhubungan negatif dengan harga saham karena peningkatan suku bunga akan mengakibatkan pemilik dana untuk mengalihkan penanamannya dari saham ke deposito. Sejak otoritas moneter meningkatkan suku bunga (serta faktor-faktor lain), IHSG terus merosot dari puncak tertinggi. Penurunan sangat drastis pernah terjadi pada waktu IHSG merosot 21\% (dari 324,0 menjadi 256,8 hanya dalam waktu satu minggu (minggu kedua September 1998) pada waktu suku bunga SBI mencapai tingkat tertinggi $71 \%$ per tahun.

b. Sektor Riil

Krisis ekonomi yang diawali dengan depresiasi nilai tukar rupiah pada bulan Juli 1997 merupakan krisis terburuk sejak pemerintahan Orde Baru yang ditandai dengan hiper-inflasi (sekitar 80\%), pertumbuhan ekonomi mengalami kontraksi yang sangat besar (15\%) dengan pengangguran mencapai 11,8 juta orang, kemiskinan meningkat dari 11,3\% jumlah penduduk tahun 1996 menjadi 39,1\% (79,4 juta pada pertengahan 1998) dan pendapatan per kapita merosot dari \$1.055,4 menjadi \$ 449,2 tahun 1998.

Dalam perkembangan selanjutnya, krisis berkembang meluas menjadi krisis sosial dan politik yang disertai dengan hilangnya kepercayaan terhadap perekonomian Indonesia. Suku bunga yang sangat tinggi dan berlangsung cukup lama serta situasi politik dan keamanan yang mewarnai perekonomian Indonesia terutama dalam triwulan II 1998 mengakibatkan perekonomian Indonesia mengalami kontraksi sangat tajam $(-16,5 \%)$, lebih parah dibandingkan dengan triwulan sebelumnya $(-7,9 \%)$.

Dengan demikian, selama semester I/1998 pertumbuhan ekonomi mengalami kontraksi yang cukup hebat. Selama krisis, kontraksi terbesar dialami oleh tiga sektor akibat depresiasi yang sangat besar dan situasi keamanan dan politik yang masih rawan, yaitu: (i) sektor industri pengolahan; (ii) sektor perdagangan, hotel dan restoran; dan (iii) sektor keuangan, persewaan dan jasa perusahaan. Di sektor industri pengolahan selain disebabkan oleh tingginya suku bunga bank, kontraksi juga disebabkan oleh besarnya pinjaman dalam valuta asing, sementara penerimaan mengandalkan pasar domestik, merosotnya permintaan dalam negeri sehingga beberapa industri mengurangi bahkan menghentikan produksi (misalnya PT. Astra Internasional sejak Juni 1998), dan penyelesaian politik yang berlarut-larut. Sektor perkebunan mengalami kontraksi terkecil karena dukungan sub-sektor perkebunan (terutama kelapa sawit) dan sub-sektor perikanan masih mampu tumbuh di atas $4 \%$.

\section{SJAFRUDIN PRAWIRANEGARA, EKONOMI ISLAM, DAN PANDANGANNYA TERHADAP MAKNA RIBA}

Sjafruddin Prawiranegara (1911-1989) dilahirkan di Anyar Kidul, Banten pada tanggal 28 Februari 1911 sebagai anak kedua dari Raden Arsjad Prawiraatmadja yang saat itu menjadi camat. Ayahnya seorang mēnak Sunda, sementara ibunya berdarah Minangkabau. Beliau wafat di Jakarta 15 Februari 1989 dalam usia 78 tahun. Perjuangan dan kepahlawanan Sjafruddin yang monumental adalah ketika membentuk dan memimpin Pemerintah Darurat 
Republik Indonesia (PDRI) tahun 1948, berkedudukan di Halaban, Payakumbuh, Sumatera Barat. Hingga akhir hayatnya aktif dalam kegiatan dakwah Islam. Pada tahun 2012 pemerintah menganugerahkan gelar Pahlawan Nasional kepada almarhum Mr. Sjafruddin Prawiranegara. Sjafrudin Prawiranegara juga merupakan tokoh yang sangat berengaruh pada masa awal kemerdekaan, berbagai jabatan penting pernah beliau emban. Mulai dari menjadi Gubernur Bank Indonesia, Wakil Perdana Menteri dan pernah menjabat sebagai Ketua Pemerintah Darurat Republik Indonesia. ${ }^{16}$

Menurut Sjafruddin, ilmu ekonomi pada dasarnya diciptakan oleh rasa kurang dan takut akan kekurangan. Rasa takut terhadap hari depan, takut kekurangan akan bahan-bahan hidup sehari-hari, inilah yang mendorong manusia berusaha mengumpulkan dan memperbanyak. Perasaan takut ini dapat menyebabkan manusia menjadi makhluk yang rakus dan tamak, yang tidak mempunyai perasaan belas kasihan terhadap sesama manusia. Sebaliknya, agama mengajarkan kepada manusia untuk menjauhkan perasaan takut itu sejauh-jauhnya. Yang wajib ditaati dan ditakuti hanyalah Tuhan. Jika orang sungguh-sungguh percaya dan taat terhadap Tuhan, maka orang tidak perlu takut akan mati kelaparan. Dia yakin Tuhan akan dengan mudah melimpahkan rahmat dan berkat-Nya kepada hambahamba yang taat dan mengerjakan segala apa yang diperintahkan oleh Tuhannya. ${ }^{17}$

Dari sini terlihat bahwa sistem ekonomi yang hendak dibangun dan dikembangkan oleh Sjafruddin bukanlah sistem ekonomi liberalis dan atau sosialis Marxis, tetapi sebuah sistem ekonomi yang lain dari keduanya. Dia menyebutnya dengan "sistem ekonomi jalan tengah". Sjafruddin melihat sistem ekonomi jalan tengah ini merupakan salah satu sudut dari sebuah segitiga. Kalau kita ibaratkan sebuah segitiga, dua buah sudut di alas segitiga tersebut adalah liberalisme dan sosialisme, maka sudut ketiga yang terletak dipuncak adalah sistem ekonomi Islam. Dalam sistem ini, ajaran agama merupakan sumber nilai utama, apalagi bagi umat Islam, alquran dan Sunah merupakan pedoman dan petunjuk bagi semua pelaku ekonomi dalam berpikir dan bertindak. Semua pihak, baik produsen, distributor, konsumen, serta pemerintah harus tunduk dan patuh kepada nilai dan norma yang telah ditentukan oleh agama. Untuk itu, menurut Sjafruddin, dalam usaha mencari nafkah itu kita harus memperhatikan dan memegang teguh norma-norma moral yang tinggi. Kaum muslimin tidak boleh mencuri, menipu, memaksa secara kasar atau halus, menyalahgunakan amanah dan lain-lain sebagainya, untuk memperoleh keuntungan ${ }^{18}$

Menarik untuk dicermati pandangan Sjafruddin Prawinegara terhadap makna riba dalam al-Qur`an. Menurutnya untuk memahami arti riba harus diperhatikan beberapa faktor sebagai berikut. Pertama, terjemah harfiyah kata riba itu memang berarti tambahan. Kedua, lawan riba adalah keuntungan dari jual beli yang bersih, yang berdasarkan

16 "Ekonomi Tak Bisa Dipisahkan Dari Agama: Mengenang Sjafruddin Prawiranegara," Fuad Nasar's News (blog), 19 Mei 2016, https://fuadnasar.wordpress.com/2016/05/19/ekonomi-tak-bisadipisahkan-dari-agama-mengenang-sjafruddin-prawiranegara/.

${ }_{17}$ Anwar Abbas, "Agama dan Kehidupan Ekonomi Menurut Sjafruddin Prawiranegara," Al-Iqtishad: Journal of Islamic Economics 5, no. 1 (31 Oktober 2015): 73, https://doi.org/10.15408/aiq.v5i1.2110.

18 Sjafruddin Prawiranegara, Memperkenalkan Asas dan Tujuan Husami dalam Ajip Rosidi (ed.), Sjafruddin Prawiranegara, Ekonomi dan Keuangan Makna Ekonomi Islam, 1 ed. (Jakarta: CV. Haji Masagung, 1988), 250. 
kesukaan timbal balik antara yang membeli dan yang menjual. Jika kita menelaah lebih komperhemsif mengenai peranan suku bunga dalam perekonomian suatu negara maka pendapat Sjafrudin mengenai tidak samanya riba dan bunga bank menjadi sesuatu yang sangat masuk akal.

Secara terminologi, riba oleh Sjafruddin didefinisikan sebagai, segala keuntungan yang diperoleh berdasarkan transaksi atau perjanjian di mana satu pihak menyalahgunakan kedudukan ekonominya yang kuat untuk mengambil keuntungan melampaui batas dari pihak lawannya yang kedudukan ekonominya lemah. Definisi ini menurut Sjafruddin dapat disimpulkan dari penafsirannya atas QS. al-Baqoroh ayat 275 dengan menggunakan surat an-Nisa ayat 29 sebagai alatnya. Dengan definisi dan tafsirannya atas ayat riba ini, ia mempertanyakan pandangan umumnya ulama yang membawa pengertian riba pada persoalan bunga kredit. Menurutnya pandangan yang umum di kalangan umat Islam Indonesia saat itu seakan mengatakan bahwa setiap bunga bank berapapun kecilnya adalah riba dan oleh karenaya haram sedangkan keuntungan berlebihan dalam transaksi jual beli nakal tetap halal karena itu bukan riba. ${ }^{19}$

Kalau saya meminjam uang kepada B dengan bunga 6\% setahun, bunga itu adalah keuntungan dari kredit berupa pinjaman uang. Tetapi saya juga bisa menjual sebuah buku kepada B atas kredit harga tunai adalah 100,00 dalam mana sudah ada untung 30,00 dengan kredit tiga bulan saya jual buku itu dengan harga 120,00 sehingga saya mendapat tambahan keuntungan sebesar 20,00 dalam tiga bulan. Dalam teori tidaklah masuk akal, mengapa bunga atau rente yang $6 \%$ setahun itu dilarang, sedangkan untung tambahan sebesar 20,00 dalam tiga bulan atas pokok (=harga tunai) 100,00 yang merupakan tingkat bunga $80 \%$ setahun dihalalkan. ${ }^{20}$

Menurut Sjafruddin, tidaklah rasioal menamakan keuntungan yang diperoleh dari pemberian kredit berupa uang, sebagai riba dan haram. Sedangkan, keuntungan yang diperoleh dari kredit berupa penjualan barang dihalalkan. Sebab, baik yang meminjam uang maupun menjual barang berupa kredit, utang yang diakui debitur dalam ke dua hal dinyatakan dengan uang, dan untung yang diperoleh dalam dua hal juga diterima berupa uang. Jadi sifat keuntungan yang diperoleh dari pinjaman uang maupun barang adalah sama. Kalau yang satu dinamakan riba, maka yang lainpun harus dinamakan riba dan diharamkan. ${ }^{21}$

Jika keuntungan yang diperoleh dari mengutangkan barang adalah riba dan haram, maka keuntungan yang diperoleh dari penjualan tunai adalah riba pula, sebab meskipun dijualnya tunai, artinya sekarang dengan uang tunai, tetapi pembeliannya telah dilakukan beberapa waktu, misalnya 1 bulan lebih dahulu. Contoh mengenai penjualan buku misalnya, dalam waktu satu bulan saja pedagang buku mendapatkan laba 30,00 dan 20,00 atas pokok 70,00 . Dengan kata lain, dalam satu tahun tingkat bunga atau keuntungannya adalah $514 \%$.

${ }_{19}$ Muhammad Mansur, "Pandangan Syafruddin Prawiranegara Terhadap Bunga Bank" 3, no. 1 (2017): 152.

20 Sjafruddin Prawiranegara, Ekonomi dan Keuangan; Makna Ekonomi Islam (Jakarta: Gita Karya, 1988), 160.

21 Prawiranegara, 284. 
Justru ini yang lebih dicela dibandingkan dengan pihak yang meminjamkan uang dengan bunga $6 \%$ setahun. ${ }^{22}$

Kriteria riba menurut pandangan Sjafruddin bukanlah keuntungan yang diperoleh dari pinjaman uang atau dari kredit lain, justru riba adalah segala keuntungan yang diperoleh berdasarkan transaksi atau perjajian dimana satu pihak menyalahgunakan kedudukan ekonominya yang kuat untuk mengambil keuntungan yang melewati batas dari pihak lawannya yang lemah. Di dalam al-Quran maupun hadis ataupun menurut logika biasa tidak ada alasan mengharamkan bunga yang normal. ${ }^{23}$

Riba itu tetap ada dan tetap haram. Tetapi paham riba itu tidak lain hanya didasarkan kepada keadaan zaman dulu di negeri Arab dan negara-negara di sekitarnya, dimana bentuk exploitation de i'homme par i'homme (pemerasan manusia atas sesama manusia) terutama atas peminjaman uang emas dan perak, atau barang-barang lain dengan pemungutan bunga sangat tinggi oleh tukang-tukang ceti dan pedagang-pedagang yang tamak dan kejam. Riba yang paling jahat saat ini justru terdapat pada perdagangan tunai dengan adanya monopolimonopoli produksi atau perdagangan. ${ }^{24}$

Kutipan berikut adalah salah satu indikator tentang sumber atau referensi pemikiran Sjafruddin berupa konsepsi kontektualis yang mencirikan penafsiran Fazlur Rahman yang lazim dikenal sebagai teori double movement. Mengenai soal riba, saya pernah membaca uraian Tuan A. Hassan dalam pembela Islam dan suatu buku karangan seorang sarjana Pakistan yang namanya saya lupa. Tetapi karena sempitnya waktu saya tidak sempat mempelajari kembali karangan-karangan yang dimaksud, saya hanya mengutip dari ingatan saya saja. ${ }^{25}$

Ahmad Hassan adalah seorang tokoh PERSIS dan seorang sarjana dari pakistan yang dikatakan oleh Sjafruddin adalah Fazlur Rahman. Melihat pada kenyataan tentang gaya tafsir tematiknya, yakni tafsir Quran bi al-Quran adalah gaya tafsirnya Rahman. ${ }^{26}$ Buku Rahman ini dicetak tahun 1988 dan pada tahun 1970 Fazlur Rahman menetap di Universitas Chicago sebagai Professor.

\section{KEBIJAKAN MONETER BERBASIS SUKU BUNGA DALAM PERSPEKTIF EKONOMI ISLAM ALA SJAFRUDDIN PRAWIRANEGARA}

Pandangan Sjafruddin terhadap bunga bank memposisikan dirinya sebagai seseorang ahli ekonomi muslim yang melihat bunga bank dari kacamata moderen yang kontektualis, sehingga untuk mengidentifikasi makna sebuah lafal dalam sebuah ayat, dia perlu melihat lebih dulu kontek kata dan ayat tersebut. Dalam kasus ini, ia tidak terburu-buru mengidentifikasi riba sebagai bunga kredit atau pinjaman terutama oleh bank. Surat alBaqarah ayat 275 sebagai basis keharaman riba menurutnya menunjukkan bahwa riba mirip

\footnotetext{
22 Prawiranegara, 284.

23 Prawiranegara, 185-86.

${ }^{24}$ Syafrudin Prawiranegara, Islam Dilihat Dengan Kacamata Modern (Jakarta: Yayasa Idayu, 1975), 176.

${ }^{25}$ Prawiranegara, Ekonomi dan Keuangan; Makna Ekonomi Islam, 277.

26 Fazrul Rahman, Islam (Terjemahan) (Bandung: Pustaka, 1994), vi.
} 
dengan perdagangan, hanya saja karena terkandung kebatilan didalamnya maka ia diharamkan. Di sini ia ingin menegaskan bahwa, kata riba dalam ayat ini tidak terkait dengan pinjaman dari lembaga keuangan seperti halnya bank. Artinya untuk mendapatkan pembacaan yang komprehensif tidak partikularistik atau mistik terhadap term "riba".

Sjafruddin merasa perlu merujukkan terma riba yang kedua kepada terma riba yang pertama dalam ayat ini. Dalam ayat di atas, term riba yang pertama di persamakan dengan proses jual beli, berarti, term riba yang kedua menurut Syafruddin muncul terkait dengan proses perdagangan. Dengan kata lain, term riba lebih dekat dengan kontek transaksi jual beli ketimbang dengan transaksi pinjaman atau transaksi kredit dengan bank yang notabene adalah lembaga keuangan modern.

Untuk mengidentifikasi kontek perdagangan yang memunculkan fenomena riba yang dilarang dalam ayat ini, Syafruddin menemukan basis kontekstualisasinya dalam Surat AnNisa ayat 29. Dalam ayat ini, digambarkan terdapat 2 model transaksi jual beli yakni yang dilarang dan yang tidak dilarang. Transaksi jual beli yang dilarang dalam ayat ini disebut dengan transaksi yang batil sedangkan transaksi yang halal adalah transaksi jual beli atas dasar suka sama suka. Perdagangan yang batil inilah yang disebut riba, karena perdagangan yang batil merupakan perdagangan yang tidak terjadi di atas prinsip sukarela. Disebut tidak atas dasar prinsip sukarela karena di dalam transaksi perdagangan semacam ini terkandung unsur keterpaksaan dari salah satu diantara dua pihak yang bertransaksi.

Perdagangan seperti ini disebut batil dan karenanya disebut riba sehingga diharamkan karena transaksi ini dilakukan oleh penjual yang kuat posisi ekonominya lalu dia memaksa untuk mengambil keuntungan di luar batas kewajaran dari pihak pembeli yang lemah posisi ekonominya. Hanya lantaran si pembeli sangat perlu untuk mendapatkan barang dagangan itu, maka "terpaksa" melakukan transaksi tersebut, meskipun tahu bahwa keuntungan si penjual melampaui batas kewajaran. Konteks inilah yang memunculkan term riba, sehingga menurut Sjafruddin ketika riba dipahami sebagai bunga bank merupakan pemahaman yang tidak kontekstual.

Bunga bank yang dilakukan dengan tidak berdasarkan pada prinsip ekspolitasi bukan merupakan riba. Menurutnya, baik laba maupun bunga, apakah tetap atau naik turun, jika didasarkan pada persetujuan yang bersih dan ikhlas adalah sah dalam pandangan Allah Swt. Sebalikhya laba yang berlebihan, termasuk bunga yang berasal dari perdagangan barang atau uang yang diperoleh secara tidak jujur misalnya hasil menipu, adalah riba, dan ini tidak hanya berlaku atau ditujukan hanya pada bank. Dengan kata lain lembaga atau institusi apapun namanya jika memperoleh keuntungan atau bunga sebagai hasil dari penipuan atau kebohongan maka itu pun namanya riba,. Sebab perbuatan itu merupakan pelanggaran terhadap ketentuan Allah SWT, manusia harus berbuat baik dan tidak menipu serta menekan hambanya

Dengan demikian menurut analisis yang dilakukan penulis bahwa dalam perspektif Syafruddin Prawiranegara, bunga Bank bisa disebut riba apabila terdapat unsur-unsur sebagai berikut: pertama, pihak pemberi pinjam atau kredit member bunga yang mengandung eksploitasi, artinya pemberi pinjam atau kredit secara langsung mempunyai niat untuk memperoleh keuntungan sebesar-besarnya meskipun pada akhirnya si peminjam uang atau kredit tidak akan mampu membayarnya atau sekalipun mampu maka usahanya bangkrut. Kedua, sama sekali tidak ada unsur menolong melainkan yang ada hanya murni 
bisnis dan mencari laba di atas penderitaan orang lain. Melihat pandangan dan pendapat Syafruddin Prawiranegara tersebut, maka penulis kurang setuju dengan pikiran dan argumentasi yang dikemukakan yang pada intinya penulis tidak setuju bahwa bunga bank yang masih dalam batas wajar dibolehkan. Menurut penulis bila bunga bank tidak diharamkan maka masalahnya menjadi rumit. Karena bank Islam saat ini sudah berdiri dengan baik, maka ia akan goyah jika berpegang teguh pada pendapat Syafruddin Prawiranegara.

Pendapat Syafruddin Prawiranegara sangat kontradiktif karena jarang sekali kalau tidak boleh dikatakan tidak ada orang atau lembaga yang mengulurkan pinjaman hanya atas dasar menolong tanpa mencari keuntungan. Selain itu logika Syafruddin Prawiranegara kurang logis, dikatakan demikian karena dia tidak bisa memberi ukuran yang pasti tentang batasan bunga yang wajar dan bunga yang mengandung unsur eksploitasi. Karena itu pendapatnya mungkin lebih tepat menghalalkan bunga bank pada sat belum ada bank Islam, ini mungkin bisa dikategorikan darurat. Tapi saat ini kondisi darurat sudah tidak bisa dijadikan alasan karena setiap orang bisa menjadi nasabah bank Islam. Oleh sebab itu penulis berpendapat bahwa pemikirannya tentang penghalalan bunga sudah tidak relevan lagi.

\section{PENUTUP}

1. Bahwa mekanisme instrumen kebijakan moneter yang diterapkan dinegara kita merupakan kebijakan yang tidak bisa diandang secara sempit bahwa tidak sesuai dengan syariah. Mekanisme yang dijalankan pemerintah yang berbasis suku bunga memiliki tujuan yang sangat baik yaitu outunya untuk mengendalikan harga-harag dipasaran dan mempertahankan tingkat inflasi Pandangan Sjafruddin terhadap bunga Bank dari kacamata modern-kontektualis, untuk mengidentifikasi makna sebuah lafal dalam sebuah ayat, dia perlu melihat lebih dulu kontek kata dan ayat tersebut, sehinga tidak terburuburu mengidentifikasi riba sebagai bunga kredit atau pinjaman terutama oleh bank. Menurutnya riba mirip dengan perdagangan, hanya saja karena terkandung kebatilan didalamnya maka ia diharamkan namun kata riba dalam ayat al-Quran tidak terkait dengan pinjaman dari lembaga keuangan seperti halnya Bank. Dengan kata lain, term riba lebih dekat dengan konteks transaksi jual beli ketimbang dengan transaksi pinjaman atau transaksi kredit dengan Bank yang notabene adalah lembaga keuangan modern. Pandangan Syafruddin ini banyak dipengaruhi oleh konsepsi kontektualis Fazlur Rahman dan Ahamad Hassan.

2. Dibandingkan dengan negara Islam lainnya, Indonesia termasuk negara yang telah menjalankan instrumen kebijakan moneter syariah bersama dengan beberapa negaranegara lainnya. Namun bila dilihat dari progresnya Indonesia termasuk mengalami perlambatan dibandingkan negara tetangga. Karena Indonesia masih berkutat dengan cara-cara kapitalis dalam menyelesaikan kebijakan-kebijakan ekonomi. Bahkan sebagian masyarakat muslim sendiri masih meragukan terhadap metode syariah. sehingga benarbenar memperpanjang kondisi dan memperparah keadaan ekonomi saat ini.

3. Dari contoh kasus yang terjadi pada saat Indoensia mengalami krisis ekonomi di tahun 1997-1998, kita dapat melihat bahwa fungsi pengaturan suku bunga sangatlah krusial. 
Toufan Aldian Syah, Jamal Abdul Aziz

Kebijakan penetapan suku bunga akan langsung berdamak pada konsidi perekonomian baik pada sektor perbankan dan pasar modal, maupun dampaknya pada sektor riil.

\section{DAFTAR PUSTAKA}

Abbas, Anwar. "Agama dan Kehidupan Ekonomi Menurut Sjafruddin Prawiranegara." AlIqtishad: Journal of Islamic Economics 5, no. 1 (31 Oktober 2015). https://doi.org/10.15408/aiq.v5i1.2110.

Arifin, Sjamsul. "Efektifitas Kebijakan Suku Bunga Dalam Rangka Stabilisasi Rupiah Di Masa Krisis." Buletin Ekonomi Moneter dan Perbankan 1, no. 3 (11 Oktober 2003): 1-26.

Ascarya. Instrumen-Instrumen Pengendalian Moneter. Buku Seri Kebanksentralan No. 3. Jakarta: Pusat Pendidikan Dan Studi Kebanksentralan (PPSK) Bank Indonesia, 2002.

Bofinger, Peter. Monetary Policy: Goal, Institutions, Strategies and Instrument. New York: Oxford University Press, 2001.

Fuad Nasar's News. "Ekonomi Tak Bisa Dipisahkan Dari Agama: Mengenang Sjafruddin Prawiranegara," 19 Mei 2016. https:/ fuadnasar.wordpress.com/2016/05/19/ekonomitak-bisa-dipisahkan-dari-agama-mengenang-sjafruddin-prawiranegara/.

Mankiw, Gregory. Makro Ekonomi. Keenam. Jakarta: Erlangga, 2007.

Mansur, Muhammad. "Pandangan Syafruddin Prawiranegara Terhadap Bunga Bank" 3, no. 1 (2017): 16.

Manurung. Uang, Perbankan, dan Ekonomi Moneter. Jakarta: Fakultas Ekonomi Universitas Indonesia, 2004.

McNellis, dan David Bigman. "Inventory Management and Economic Instability in High Inflation Economies: A Macrodynamic Simulation.” Journal of Policy Modeling 10, no. 2 (1988): 224-47.

Miskhin, F.S. The Economics of Money, Banking and Financial Markets. Seventh. New York: Pearson Addison Wesley Longman, 2004.

Muhamad. Ekonomi Moneter Islam. 1 ed. Yogyakarta: UII Press, 2018.

Prawiranegara, Sjafruddin. Ekonomi dan Keuangan ; Makna Ekonomi Islam. Jakarta: Gita Karya, 1988.

- Memperkenalkan Asas dan Tujuan Husami dalam Ajïp Rosidi (ed.), Sjafruddin Prawiranegara, Ekonomi dan Keuangan Makna Ekonomi Islam. 1 ed. Jakarta: CV. Haji Masagung, 1988.

Prawiranegara, Syafrudin. Islam Dilihat Dengan Kacamata Modern. Jakarta: Yayasa Idayu, 1975.

Rahman, Fazrul. Islam (Terjemahan). Bandung: Pustaka, 1994. 
Penerapan Suku Bunga Bank Indonesia sebagai Instrumen Utama Kebijakan Moneter di Indonesia Perspektif Ekonomi Islam ala Syafruddin Prawiranegara

Rivai, Veithzal. Islamic Risk Management for Islamic Bank. Gramedia Pustaka Utama, 2013.

Solihin, dan Suseno. Uang: Pengertian, Penciptaan, dan Peranannya dalam Perekonomian. Buku Seri Kebanksentralan No.1. Jakarta: Pusat Pendidikan Dan Studi Kebanksentralan (PPSK) Bank Indonesia, 2002.

Sudirman, I Wayan. Kebijakan Fiskal dan Moneter: Teori dan Empirikal. Prenada Media, 2017.

Iqtishadia:Jurnal Ekonomi dan Perbankan Syariah

Vol. 7 No. 2 Desember 2020 